\title{
A genetic study of Pinus parviflora on Ulleung Island of Korea, Compared to $P$. parviflora of Japan and $P$. armandii of China
}

\author{
By H.-Y. GIL ${ }^{1)}$, E. H. LeE ${ }^{1)}$, I.-Y. CHOI ${ }^{2)}$, M. S. RoH ${ }^{3)}$ and C. S. ChAnG ${ }^{1), *)}$
}

(Received 22 $2^{\text {th }}$ July 2010)

\begin{abstract}
Pinus parviflora Siebold et Zucc. on Ulleung Island, Korea, has been proposed to be more closely related to $P$. armandii Franch. because both have long leaves and seeds that are either wingless or have very short wings. Randomly amplified polymorphic DNA (RAPD) markers using nine primers and sequence analysis of the $\operatorname{trn} \mathrm{G}$ gene and the mat $\mathrm{K}$ gene and morphological characteristics of seeds and cones were used to assess the genetic relatedness of this taxon on Ulleung Island with $P$. armandii in China and $P$. parviflora in Japan. This current study showed that Pinus armandii from China, $P$. parviflora from Japan, and $P$. parviflora populations of Ulleung Island formed distinct groups that were separated from each other. $P$. parviflora from Ulleung Island grouped with $P$. parviflora from Japan, rather than $P$. armandii from China based on the RAPD dendrogram and SNPs in matK. It is believed that P. parviflora on Ulleung Island is genetically well differentiated, indicating limited gene flow from Japan, although cones and seeds of $P$. parviflora on Ulleung Island are more similar to var. parviflora in southern Japan than $P$. armandii in central China. It seems that the entities that comprise $P$. parviflora exhibit widely overlapping ranges in morphological attributes except leaf length.
\end{abstract}

Key words: Pinus parviflora, Pinus armandii, RAPD, Single nucleotide polymorphisms, matK gene, Ulleung Island.

\section{Introduction}

The genus Pinus L. is generally divided into two subgenera, Strobus and Pinus (Mirov, 1967). Among the subgenus Strobus, whose common name is five-needle soft pines, native to eastern Asia, P. armandii Franch. and $P$. koraiensis Siebold \& Zucc. are known to be important for timber production, while the rest of the five-needle pines, such as $P$. parviflora Siebold et Zucc. has rather limited economic importance due to their restricted gene resources (WANG and HoNG, 2004). P. parviflora, commonly known as Japanese white pine, is distributed from southern Hokkaido to Kyushu including far eastern Russia and Ulleung Island of Korea (WILson, 1916; KaWAMOTO, 1943; LeE, 1980; OHWI, 1984).

\footnotetext{
1) Department of Forest Sciences and Research Institute for Agriculture and Life Sciences, Seoul National University.

2) National Instrumentation Center for Environmental Management, Genomics Laboratory, Seoul National University, Gwanak-gu, Seoul, 151-921, Korea.

3) USDA, ARS, US National Arboretum, Floral and Nursery Plants Research Unit, Beltsville, MD 20705, USA.

*) Corresponding author: CHIN-Sung CHAng. Department of For est Sciences and The Arboretum, Seoul National University, Seoul, 151-921, Korea. Phone 82-2-880-4758, Fax 82-2-8733560. E-Mail: quercus@plaza.snu.ac.kr.
}

Ulleung Island, late Tertiary origin from three to five million years old, is located ca. $150 \mathrm{~km}$ off the coast of Korea at $37^{\circ} 30^{\prime} \mathrm{N}$ and $130^{\circ} 51^{\prime} \mathrm{E}$. This island was then connected to the Korean peninsula and the west coast of Japan until the early Quaternary (YANG, 1996). Ulleung Island has a unique flora of ca. 180 woody species of which ten are endemic to the Island (LEE and Joo, 1958).

Information on the morphological variability of $P$. parviflora on Ulleung Island is fragmentary. Based on wing size of seeds, two different varieties of $P$. parviflora have been reported in Japan: var. pentaphylla (Mayr) Henry in southern Hokkaido and from north to central Honshu (mainly on the East side) and var. parviflora from central to western Honshu, Shikoku, and Kyushu (OHWI, 1984; YAMAZAKI, 1995; TANI et al., 2003).

More than 20 collections of seed cones with seeds of P. parviflora on Ulleung Island and specimens at the T.B. Lee Herbarium at Seoul National University and the Arnold Arboretum at Harvard University have been observed thus far. It was found that seed wings were ca. 3-5 mm in length with an appressed and vestigial structure. Pinus armandii is distributed in the southern provinces of China, i.e., Yunnan, Sichuan, Shaanxi, and Henan, and Taiwan, and southern Japan (MIRov, 1967; FU et al., 1999; YAMAZAKI, 1995; KANETANI et al., 2004) is known to have no seed wings which is one of the taxonomically important characters (WANG and HONG, 2004).

Limited observation from cultivated individuals of Japanese $P$. parviflora in Korea suggested that leaf length of $P$. parviflora from Japan is much shorter than that of $P$. parviflora on Ulleung Island. The individuals on Ulleung Island are delimited by discontinuities in the variation of leaf and seed wing characters and these patterns cannot be incorporated satisfactorily in the normal taxonomic framework. It needs confirmation since individuals on Ulleung Island can be classified as either P. armandii (WANG and HoNG, 2004) or P. parviflora (Wilson, 1916; KAWAMOTO, 1943; LeE, 1980; OHWI, 1984).

Previous studies showed that Fagus multinervis Nakai and Cotoneaster wilsonii Nakai on Ulleung Island are more related to $F$. engleriana Seemen ex Diels and C. multiflorus Bunge of central China (CHANG and JEON, 2003), while Tsuga on Ulleung Island is more related to T. diversifolia (Maxim.) Mast. of northern Japan, rather than to T. sieboldii Carriere of southeastern Japan (HAVILL et al., 2008). On the other hand, Acer takesimense Nakai, Prunus takesimensis Nakai, and Sambucus racemosa subsp. pendula (Nakai) H. I. LIM and CHIN S. CHANG on Ulleung Island have been reported as closely related species of Acer pseudosieboldianum (Pax) Kom., Prunus sargentii Rehder, and Sambucus racemosa 
subsp. kamtschatica (E. L. Wolf) Hultén of the Korean peninsula (CHANG, 1992; CHANG et al., 2004; LIM et al., 2009). Most of the flora of Ulleung Island is considered to have originated from either the Asian mainland including the Korean peninsula and Central China or the Japanese archipelago (PFosser et al., 2002; PFOSSER et al., 2005; MAEKAWA and SHIDEI, 1974).

Molecular markers generated by RAPD (WILLIAMS et al., 1990; Hicks et al., 1998; LEIBENGUTH et al., 1998; RoH et al., 2007a; SCHEEPERs et al., 1997) and single nucleotide polymorphism (SNP) (BROOKES, 1999; RAFALSKI, 2002; HsU et al., 2008; RoH et al., 2007b; Yoon et al., 2008) have been useful in studying genetic relationships, and very critical when genetic diversity or identification of certain germplasm cannot be effectively understood based on certain morphological characters. SNPs are the most abundant sequence variations in most genomes (BROOKES, 1999). The abundance, ubiquity, and interspersed nature of SNP throughout the genome make them ideal candidates as molecular markers (RAFALSKI, 2002). Information regarding the geographic distribution and genetic differentiation of $P$. parviflora in Japan and $P$. armandii in China including $P$. parviflora on Ulleung Island may offer major clues to possible relationships. Thus, it was desirable to determine if evidence from RAPD and DNA sequence variation from SNPs of two chloroplast genes [RNA-Gly $(\operatorname{trn} \mathrm{G})$ and maturase $\mathrm{K}(\operatorname{mat} \mathrm{K})$ ] corresponds to the cur- rent disposition of species based on morphology (WANG and HoNG, 2004; LeE, 1980; OHWI, 1984).

\section{Materials and Methods}

\section{Plant materials}

Most of the samples were collected from wild populations or known provenance as indicated in Table 1. Eight individuals of Pinus armandii were collected from the US National Arboretum (NA, Washington, DC, USA), the Arnold Arboretum (AA, Jamaica Plains, MA, USA), and Quarryhill Botanical Gardens (QHBG, Glen Allen, CA, USA). Also, 21 individuals of $P$. parviflora collected from Ulleung Island, Gyeongsangbuk-do, Korea were used in this study. Herbarium specimens from the material collected are stored at the T. B. Lee Herbarium of the Arboretum of Seoul National University (SNUA). Two individuals of $P$. parviflora from Nigata and Hokkaido were treated as var. pentaphylla here (TANI et al., 2003), but samples of unknown origin were recorded as $P$. parviflora including those from Ulleung Islands, not as $P$. parviflora var. parviflora here because of difficulty of assignment of an infraspecific rank. In addition, four samples of unknown wild origin of $P$. parviflora were assigned as $P$. parviflora. Pinus lambertiana Doug. and $P$. armandii $\times P$. lambertiana were included in this study as outgroups (Table 1).

Table 1. - Individual number (NO.), location, and species names for 32 individuals of Pinus parviflora, $P$. armandii, and other taxa.

\begin{tabular}{|c|c|c|c|}
\hline No. & Species & General Location & GPS and collection information \\
\hline 1 & P. armandii & $\begin{array}{l}\text { US National } \\
\text { Arboretum (NA) } \\
64752.003\end{array}$ & Shaanxi, China, $2,400 \mathrm{~m}$ \\
\hline 2 & P. armandii & NA 64752.004 & Shaanxi, China, $2,400 \mathrm{~m}$ \\
\hline 3 & P. armandii & $\begin{array}{l}\text { Quarryhill Botanical } \\
\text { Garden (QHBG), } \\
1991.134\end{array}$ & Sichuan, China \\
\hline 4 & P. armandii & $\begin{array}{l}\text { Arnold Arboretum } \\
\text { (AA), Jamaica Plain, } \\
\text { MS 729-83A }\end{array}$ & $\begin{array}{l}\text { Cultivated plant of known wild } \\
\text { (indirect) origin, Sichuan, China }\end{array}$ \\
\hline 5 & P. armandii & AA $419-84 \mathrm{~A}$ & $\begin{array}{l}\text { Cultivated plant of known wild } \\
\text { (indirect) origin, Mt. Taipei, Shanxii, } \\
\text { China }\end{array}$ \\
\hline 6 & P. armandii & AA $24-49$ A & Collected wild origin. Sichuan, China. \\
\hline 7 & P. armandii & AA $472-54 \mathrm{~B}$ & $\begin{array}{l}\text { Cultivated plant of unknown wild } \\
\text { origin. }\end{array}$ \\
\hline 8 & P. armandii & AA $323-87 \mathrm{~B}$ & $\begin{array}{l}\text { Cultivated plant of known (indirect) } \\
\text { wild origin. Sichuan, China. }\end{array}$ \\
\hline 9 & $\begin{array}{l}\text { P. parviflora var. } \\
\text { pentaphylla }\end{array}$ & AA $1539-71 B$ & $\begin{array}{l}\text { Received as } P \text {. pentaphylla. Ofuna } \\
\text { Bot. Garden, Kanagawa, } \\
\text { Japan. Unknown origin. }\end{array}$ \\
\hline 10 & P. parviflora & AA $893-49$ A & $\begin{array}{l}\text { Yokohama Nursery, Japan via Larz } \\
\text { Anderson, Brookline, MA, } \\
\text { USA. Unknown origin. }\end{array}$ \\
\hline
\end{tabular}


Table 1. - Continued.

\begin{tabular}{|c|c|c|c|}
\hline No. & Species & General Location & GPS and collection information \\
\hline 11 & $\begin{array}{l}\text { P. parviflora var. } \\
\text { pentaphylla }\end{array}$ & AA $192-90$ & The same as $9 \mathrm{~A}$. \\
\hline 12 & $\begin{array}{l}\text { P. parviflora var. } \\
\text { pentaphylla }\end{array}$ & AA $1732-77 \mathrm{~B}$ & $\begin{array}{l}\text { Collected directly from wild. Mt. } \\
\text { Apoi, Hidaka Dist. Hokkaido Pref. } \\
\text { Japan }\end{array}$ \\
\hline 13 & P. parviflora & Korea 058 & 440m, Taeha, Ulleung Island, Korea. \\
\hline 14 & $P$. parviflora & Korea 059-1 & $440 \mathrm{~m}$, Ulleung Island, Korea \\
\hline 15 & P.parviflora & Korea 059-2 & 440m, Ulleung Island, Korea \\
\hline 16 & $P$. parviflora & Korea 059-3 & $440 \mathrm{~m}$, Ulleung Island, Korea \\
\hline 17 & P. parviflora & Korea 064-1 & $440 \mathrm{~m}$, Ulleung Island, Korea \\
\hline 18 & P. parviflora & Korea $064-2$ & 440m, Ulleung Island, Korea \\
\hline 19 & $P$. parviflora & Korea 064-3 & 440m, Ulleung Island, Korea \\
\hline 20 & $P$. parviflora & Korea 1 & $300 \mathrm{~m}$, Namseo, Ulleung Island, Korea \\
\hline 21 & P. parviflora & Korea 4 & $300 \mathrm{~m}$, Namseo, Ulleung Island, Korea \\
\hline 22 & $P$. parviflora & Korea 8 & $300 \mathrm{~m}$, Namseo, Ulleung Island, Korea \\
\hline 23 & P. parviflora & Korea 16 & $300 \mathrm{~m}$, Namseo, Ulleung Island, Korea \\
\hline 24 & $P$.parviflora & Korea 19 & $300 \mathrm{~m}$, Namseo, Ulleung Island, Korea \\
\hline 25 & $P$. parviflora & Korea 21 & $300 \mathrm{~m}$, Namseo, Ulleung Island, Korea \\
\hline 26 & $P$. parviflora & Korea 7 & $300 \mathrm{~m}$, Namseo, Ulleung Island, Korea \\
\hline 27 & $\begin{array}{l}\text { P. parviflora var. } \\
\text { pentaphylla }\end{array}$ & Niigata, Japan 1 & $\begin{array}{l}200 \mathrm{~m} \text {, Mt. Kakajo, Sanjo-Shi, Niigata, } \\
\text { Japan. }\end{array}$ \\
\hline 28 & $\begin{array}{l}\text { P. parviflora var. } \\
\text { pentaphylla }\end{array}$ & Niigata, Japan 3 & $\begin{array}{l}200 m \text {, Mt. Kakajo, Sanjo-Shi, Niigata, } \\
\text { Japan. }\end{array}$ \\
\hline 29 & $\begin{array}{l}\text { P. parviflora var. } \\
\text { pentaphylla }\end{array}$ & AA $16568 \mathrm{D}$ & $\begin{array}{l}\text { Received as } P \text {. parviflora. Sapporo, } \\
\text { Japan }\end{array}$ \\
\hline & P. parviflora & AA $195-65$ A & $\begin{array}{l}\text { Received as P. parviflora } \\
\text { 'Brevifolia'. From US National }\end{array}$ \\
\hline 30 & & & $\begin{array}{l}\text { Arboretum, Washington, DC. From a } \\
\text { cultivated plant of unknown wild } \\
\text { origin. }\end{array}$ \\
\hline 31 & P. lambertiana & AA $16552 D$ & $\begin{array}{l}\text { Grafted plant from a cultivated plant of } \\
\text { unknown wild origin. C. A. Dana, Glen } \\
\text { Cove, NY. }\end{array}$ \\
\hline 32 & $\begin{array}{l}\text { P.armandii } x \\
\text { P. Lambertiana }\end{array}$ & AA $534-59 \mathrm{~A}$ & $\begin{array}{l}\text { Cultivated plant. Unknown wild origin. } \\
\text { Crossed by Albert Johnson, } 1952 \text { from } \\
\text { Bussey Institute. }\end{array}$ \\
\hline
\end{tabular}

\section{$D N A$ extraction, polymerase chain reaction and $R A P D$}

Total genomic DNA was extracted from dried needles (50 mg) using the cetyl trimethyl ammonium bromide (CTAB) method (Doyle and Doyle, 1987). DNA was quantified with a NanoDrop D-1000 Spectrophotometer (Thermo Fisher Scientific Waltham, MA, USA). Nine informative primers (OPA4, OPA15, OPA16, OPB9, OPB11, OPC9, OPC14, OPC16, and OPC19) produced informative polymorphic bands were chosen from 23 random primers (kits A, B, and C; Operon Technologies, Alameda, CA) for final analysis.

Polymerase chain reaction (PCR) for RAPD was carried out in a $25 \mu \mathrm{l}$ reaction volume using $10 \mathrm{ng} / \mu \mathrm{l}$ of template DNA, 5 pM of primers, and Ready-To-Go PCR Beads (PCR bead, GE Healthcare, Buckinghamshire, UK) using the PTC-100 Programmable Thermal Cycler (MJ Research, Watertown, MA, USA). PCR amplification profiles consisted of $94^{\circ} \mathrm{C}$ for 3 min followed by 35 cycles of $94^{\circ} \mathrm{C}$ for $30 \mathrm{sec}, 37^{\circ} \mathrm{C}$ for $30 \mathrm{sec}$, and $72^{\circ} \mathrm{C}$ for $60 \mathrm{sec}$ and a final extension at $72^{\circ} \mathrm{C}$ for $3 \mathrm{~min}$. Amplified products were separated on $1.5 \%$ agarose gels $(0.5 \mathrm{x}$ TBE buffer) for $3 \mathrm{~h}$ at 120 volts, and stained with ethidium bromide. Gels were documented digitally using an Image Analyzer (AlphaImager 2000, Alpha Innotech Corp., San Leandro, CA, USA). Amplification products ranging in size from $300 \mathrm{bp}$ to $1,400 \mathrm{bp}$ were selected for scoring manually. 
Table 2. - Primer sets to amplify selected introns for Pinus armandii and P. parviflora.

\begin{tabular}{|c|c|c|c|}
\hline $\begin{array}{l}\text { Primer } \\
\text { sets }\end{array}$ & $5^{\prime}$ to 3' Sequence & $\begin{array}{l}\text { Product } \\
\text { size }(\mathrm{bp}) \\
/ \mathrm{Tm}\left({ }^{\circ} \mathrm{C}\right)^{1}\end{array}$ & NCBI acc number; definition \\
\hline$\overline{\mathrm{PA} 1}$ & $\begin{array}{l}\text { Forward TGAATGCCCAGGAATAGCAT } \\
\text { Reverse AGCTCCTTCATGGGGGATAG }\end{array}$ & $7741 / 57$ & $\begin{array}{l}\text { EF546745; P. parviflora } \\
\text { isolate PARV10S3 tRNA-Gly } \\
\text { (trn G) gene, intron; } \\
\text { chloroplast }\end{array}$ \\
\hline PA2 & $\begin{array}{l}\text { Forward TCGGATGAACCCTCTTTTTG } \\
\text { Reverse TCCTGTATCTTTGCCAGGAA }\end{array}$ & $513 / 58$ & $\begin{array}{l}\text { EF546720; } P \text {. parviflora } \\
\text { isolate PARV } 10 S 3 \text { maturase K } \\
\text { (matK) gene, partial cds; } \\
\text { chloroplast }\end{array}$ \\
\hline
\end{tabular}

${ }^{1}$ Product size of amplifications and annealing temperature (Tm).

\section{Sequence analysis and single nucleotide polymorphism}

The trn $\mathrm{G}$ gene (intron, EF546745) and matK gene (EF546720) of $P$. parviflora were obtained from GenBank (Table 2). Primers were constructed using Primer3 Input (v. 0.4.0) software (http://frodo.wi.mit.edu/cgi$\underline{\text { bin/primer3/primer3 }}$-www.cgi). Amplification was performed using $10 \mathrm{ng} / \mu \mathrm{l}$ of template DNA, $10 \mathrm{pM}$ of primers, and Ready-To-Go PCR Beads in a total volume of $25 \mu$ l, with a PTC-100 Programmable Thermal Cycler (MJ Research, Watertown, MA, USA). Amplification profiles were $94^{\circ} \mathrm{C}$ for 5 min followed by 30 cycles of $94^{\circ} \mathrm{C}$ for $1 \mathrm{~min}, 1 \mathrm{~min}$ at 57 or $58^{\circ} \mathrm{C}$ (Table 2) and $72^{\circ} \mathrm{C}$ for $1 \mathrm{~min}$, and a final extension of $5 \mathrm{~min}$ at $72^{\circ} \mathrm{C}$.

Sequencing reactions were performed with $0.5 \mu \mathrm{l}$ of PCR product, $1 \mu \mathrm{l}$ of BigDye Terminator (Version 3.1, Applied Biosystems, Foster City, CA), and $1 \mu$ of PCR primers $(1 \mathrm{pmol} / \mu \mathrm{l})$. Amplification profiles were $94^{\circ} \mathrm{C}$ for $2 \mathrm{~min}$ followed by 35 cycles of $94^{\circ} \mathrm{C}$ for $15 \mathrm{sec}, 50^{\circ} \mathrm{C}$ for $15 \mathrm{sec}, 60 \mathrm{oC}$ for $4 \mathrm{~min}$. Amplified PCR products were then sequenced with an Applied Biosystems 3730 Genetic Analyzer (PE Applied Biosystems, Foster City, Calif., USA), and the consensus sequence was blasted using the NCBI nucleotide BLAST program (http://www.ncbi. nlm.nih.gov/BLAST).

\section{Data analysis}

Bands from 300 to 1, 400bp for RAPD were scored and the corresponding matrix was used to construct dendrograms using the Molecular Evolutionary Genetics Analysis (MEGA, version 3.1) program. Clusters were inferred with the neighbor-joining method (NJ) and genetic p-distances were obtained. Robustness of the tree was tested with interior-branch (IB). The numbers for each interior branch is the percentage bootstrap value (1000 resamplings), and only values higher that $50 \%$ are shown.

\section{Morphological Analysis}

Morphological variation was measured in four characters (leaf length, cone length, seed length, and seed wing length) of 20 individuals of $P$. parviflora collected from Ulleung Island to evaluate recognition of this taxon within the $P$. parviflora complex. Ten mature cones were collected from two localities of Ulleung Island on Sept. 14, 2007 and April 18, 2008 and preserved at SNUA
(T. B. Lee Herbarium, Seoul National University). Due to insufficient collections on the island, additional ten individuals from specimens [Database, Nature (Korea Biodiversity Information System), http://www.nature.

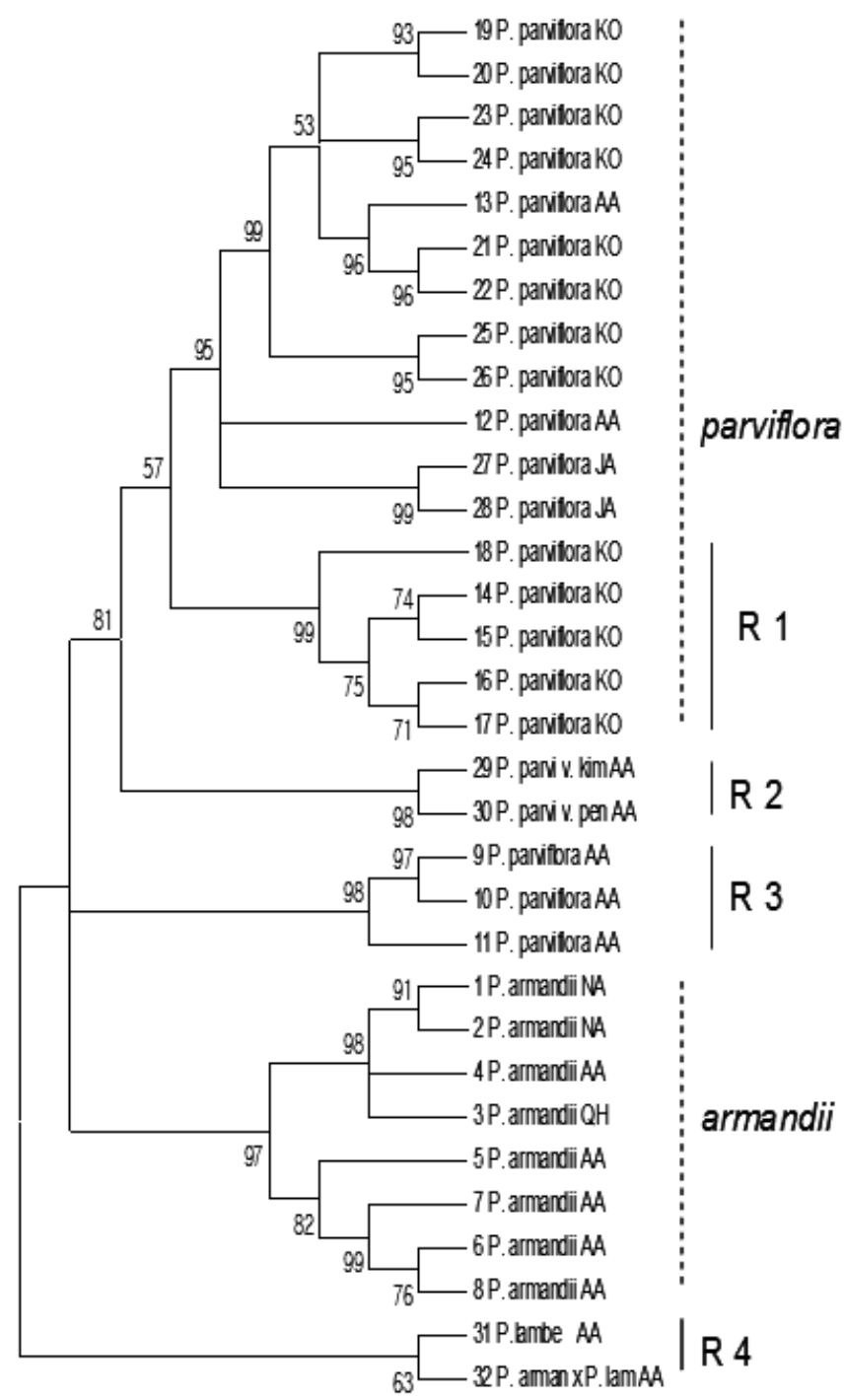

Figure 1. - The dendrogram constructed using RAPD markers by the neighbor-joining (NJ) method tested with InteriorBranch (IB) showing clustering of $P$. armandii (armandii) and P. parviflora (parviflora) with some exceptions as indicated by $\mathrm{R} 1$ through R4, and A1 through A4. Bootstrap values greater than 50 are indicated at each node. 
go.kr:9001/index.do) deposited at other institutes were measured for four characters. Morphological variation was assessed using univariate statistics (mean, maximum, minimum). Also, bivariate scatter diagrams were performed and characters associated with previous known data (BUsINSKY, 2004) were plotted.

\section{Results}

$R A P D$ analysis

In the dendrogram constructed using RAPD markers by the neighbor-joining (NJ) method tested with interior-branch (IB) (RAPD dendrogram), all individuals of $P$. armandii collected from the National Arboretum $(1,2)$, the Quarryhill Botanical Gardens (3) and the Arnold Arboretum (AA) (4, 5, 6, 7, 8) clustered together and separate from most individuals of $P$. parviflora (Fig. 1). All individuals of $P$. parviflora from Korea and from Japan formed one major cluster. Also, P. parviflora collected from Ulleung Island, Korea (14-18) formed a sub-group (R 1) and three individuals from the Arnold Arboretum and two individuals from Japan formed separate sub-groups ( $\mathrm{R} 2$ and $\mathrm{R} 3$, respectively).

Table 3. - Single nucleotide polymorphisms for Pinus parviflora isolate PARV10S3 tRNA-Gly (trn G) gene, intron; chloroplast (EF546745). Sequence analysis of individuals number 10 of $P$. parviflora, number 31 of P. lambertiana, and number 32 of $P$. armandii $\times$ $P$. lambertiana did not yield good data, and are excluded.

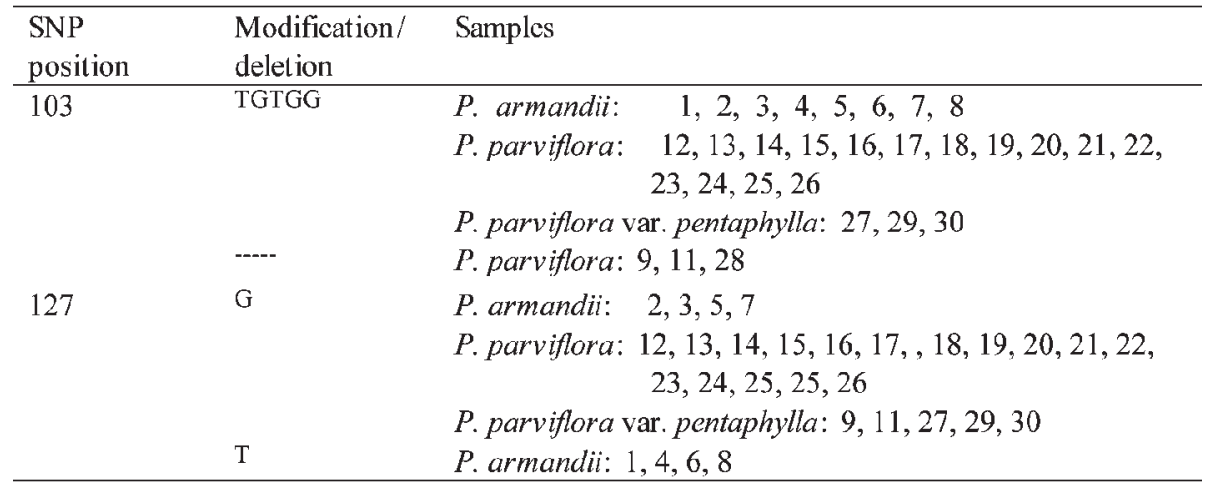

Table 4. - Single nucleotide polymorphisms for Pinus parviflora isolate PARV10S3 maturase K (matK) gene, partial cds; chloroplast EF546720.

\begin{tabular}{|c|c|c|}
\hline $\begin{array}{l}\text { SNP } \\
\text { position }\end{array}$ & $\begin{array}{l}\text { Modification/ } \\
\text { deletion }\end{array}$ & Species and individual number (refer to Table 1$)^{1}$ \\
\hline \multirow[t]{5}{*}{116} & $\mathrm{C}$ & $\begin{array}{l}P . \text { armandii: } 1,2,3,4,5,6,7,8 \\
P . \text { armandii } \times P . \text { lambertiana: } 32\end{array}$ \\
\hline & A & $\begin{array}{l}\text { P. parviflora: } \begin{array}{l}10,13,14,15,16,17,18,19,20,21, \\
22,23,24,25,26\end{array} \\
\begin{array}{l}\text { P. parviflora var. pentaphylla: } 9,11,27,28,29,30 \\
\text { P. lambertiana: } 31\end{array}\end{array}$ \\
\hline & TTTCTTCTCT & P. parviflora: 10 \\
\hline & & P. parviflora var. pentaphylla: $9,11,27,28,29,30$ \\
\hline & -'I'T'----- & P. armandii $\times P$. lambertiana: 32 \\
\hline \multirow[t]{3}{*}{144} & TT------ & P. lambertiana: 31 \\
\hline & ------- & $\begin{array}{l}\text { P. armandii: } 1,2,3,4,5,6,7,8 \\
\text { P. parviflora: } 13,14,15,16,17,18,19,20,21,22,23,24 \text {, } \\
25,26\end{array}$ \\
\hline & TCTT & $\begin{array}{l}\text { P. armandii: } 1,2,3,4,5,6,7,8 \\
\text { P. lambertiana: } 31\end{array}$ \\
\hline \multirow[t]{2}{*}{537} & & P. armandii $\times$ P. lamberiana: 32 \\
\hline & -- & $\begin{array}{l}\text { P. parviflora: } 13,14,15,16,17,18,19,20,21,22, \\
23,24,25,26 \\
\text { P. parviflora var. pentaphylla: } 9,11,27,28,29,30\end{array}$ \\
\hline
\end{tabular}

${ }^{1}$ Sequence analysis of individual numbers 10 and 12 of $P$. parviflora did not yield good data, and are excluded from the analysis here. 


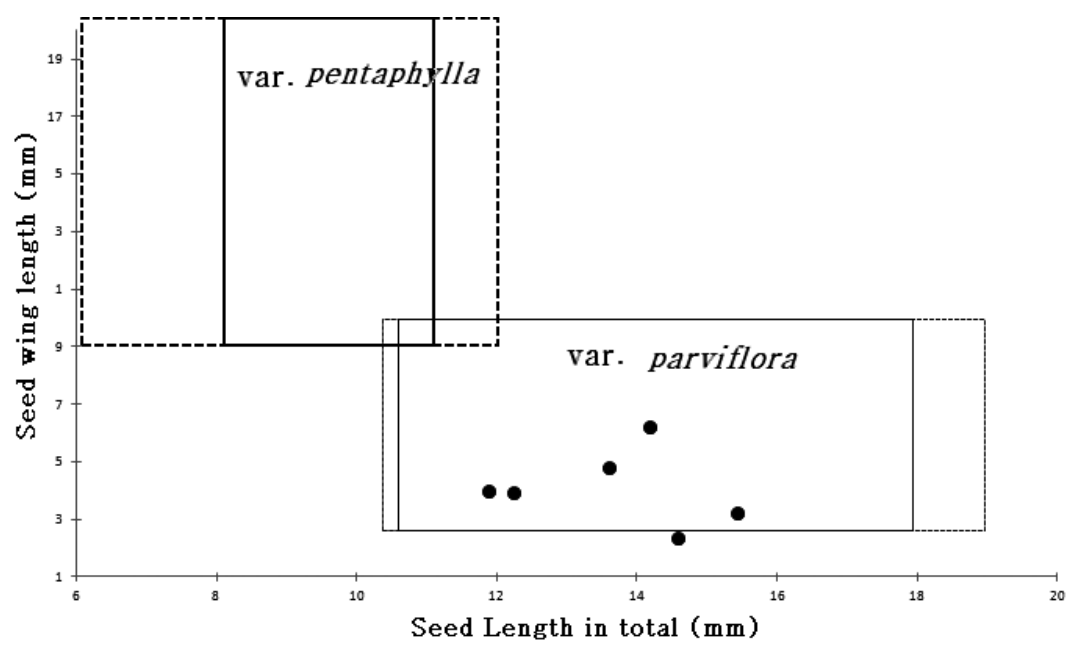

A.

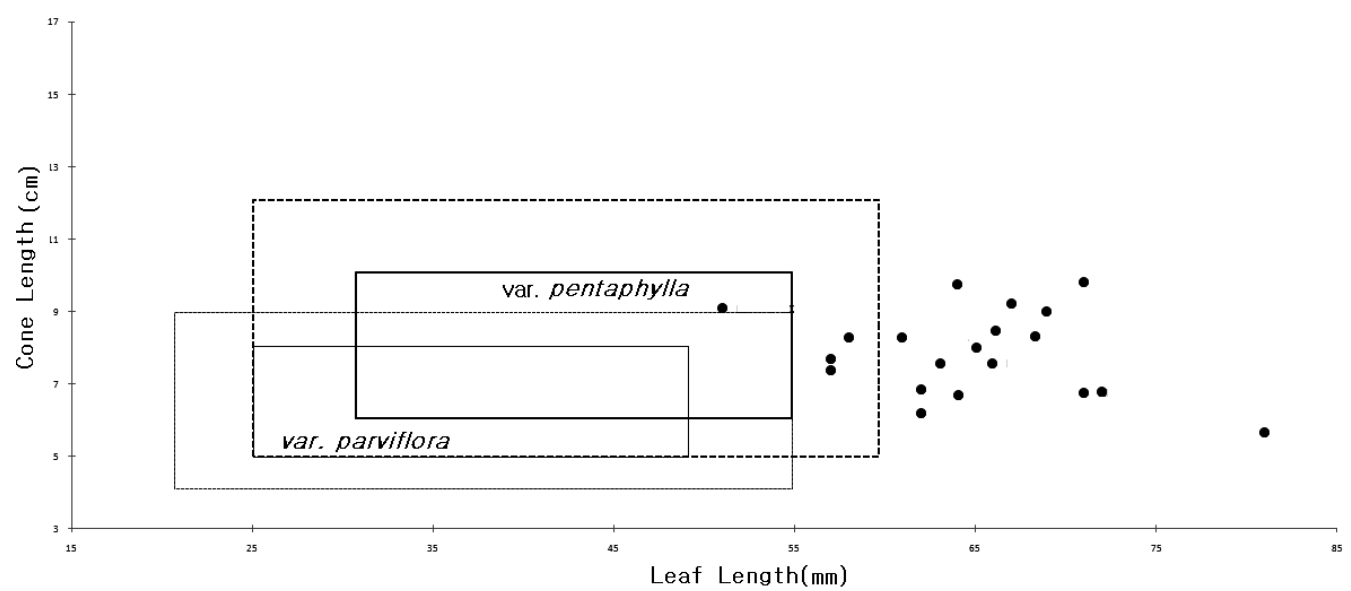

B.

Figure 2. - The scatter plots of seed characteristics (Fig. 2A) and leaf length vs. cone length (Fig. 2B) produced by the Ulleung Island individuals and var. pentaphylla and var. parviflora in Japan. Plants are assumed to be spaces in a rectangular grid, separated by mean and variance values (Businsky, 2004). Solid and dotted lines represent mean and variance range.

\section{Sequence analysis}

Sequence analysis of the Pinus parviflora trn $\mathrm{G}$ gene showed DNA sequence variation at positions 103-107 for most of $P$. armandii, $P$. parviflora var. pentaphylla, and $P$. parviflora individuals except for $P$. parviflora individuals $(9,11$, and 28) (Table 3). At SNP position 127 , only four individuals $(1,4,6$, and 8$)$ of $P$. armandii showed modification $\mathrm{T}$, while all others had $\mathrm{G}$.

More DNA sequence variation from SNPs of matK gene were noticed in $P$. parviflora and $P$. armandii (Table 4). At positions 116, all $P$. armandii $(1,2,3,4,5,6$, 7, and 8) and $P$. armandii $\times P$. lambertiana (32) had C, while all $P$. parviflora had A. At positions 144-153, two different SNPs were observed for $P$. parviflora: TTTCTTCTCT for individuals 9, 10, 11, 27, 28, 29 (Japanese origin samples) and variation for accessions $13,14,15,16,17,18,19,20,21,22,23,24,25$, and 26 (Ulleung Island samples), while all individuals of $P$. armandii showed variation at this SNP position.
Moreover, at positions 537-540, all $P$. armandii, $P$. lambertiana (31), and $P$. armandii $\times P$. lambertiana $(32)$ showed TCTT, while all individuals of $P$. parviflora had deletions.

This analysis of seed characteristics showed that individuals collected from Ulleung Island are more similar to var. pentaphylla growing in the southern part of Japan (Fig. 2A). However, the scatter plots of leaf length produced by the Ulleung Island individuals are notably longer than those produced by both var. pentaphylla and var. parviflora of Japan (BusINSKY, 2004; Fig. 2B).

\section{Discussion}

The RAPD phenogram and single nucleotide polymorphisms for matK gene showed that $P$. parviflora on Ulleung Island is more closely related to $P$. parviflora native to Japan than $P$. armandii of China, contrary to what would be expected based on the previous morphological observation. 
With the SNPs of trnG gene, $P$. armandii and $P$. parviflora were not differentiated well, since both species along with two varieties of $P$. parviflora had the same SNP at positions 103 and 127, although $P$. armandii was divided into two groups showing modifications $\mathrm{G}$ (accs 2 , 3,5 , and 7 ) or $\mathrm{T}(\operatorname{accs} 1,4,6,8)$ at position 127 . It was more useful to use $m a t \mathrm{~K}$ than $\operatorname{trn} \mathrm{G}$ gene to effectively differentiate between $P$. armandii and $P$. parviflora, between $P$. armandii $\times P$. lambertiana along with $P$. armandii, and also between $P$. lambertiana with $P$. parviflora and two of its varieties.

The RAPD dendrogram seems more reasonable than that with AFLP (not presented). Despite the potential limitation of using RAPD markers (JONES et al., 1997), they can be effectively used for characterization and identification of germplasm when they are supported by sequence variation in other markers such as the matK gene. This study shows clearly that RAPD markers can be effectively utilized when the access to AFLP analysis system is limited and when low quality of DNA is amplified. When the dendrogram of RAPD was compared with AFLP dendrogram, the major clustering pattern was found to be similar, but changes in minor grouping were observed. In both RAPD and AFLP analysis clustering of samples did not show any correlation with this limited geographical area of collections such as Ulleung Island.

A similar genetic relationship among sea buckthorn varieties (14 individuals of Hippophae rhamnoides L.) from China was revealed effectively by RAPD (RYUN et al., 2004) as compared to AFLP (RYUN, 2006) which suggest that RAPD is a viable tool when supported by SNPs (Joung et al., 2010).

The seed wings of individuals in mature cones from Ulleung Island may be almost absent (AHN, 1976). BUSINSKY (2004) stated that subsp. parviflora (=var. parviflora) has rudimentary and frangible seed wings $(2-9 \mathrm{~mm})$ with a mostly lacerate distal margin. On the other hand, subsp. pentaphylla (=var. pentaphylla) possesses long seed wings $(8-19 \mathrm{~mm})$ with an entire margin. Cone length [(6)7-10 cm vs (4)5-10(12) cm] with leaf length from samples of Ulleung Island was determined by the univariate analysis to be significant in separating both var. parviflora and var. pentaphylla (Fig. 2). These individuals, however, can be consistently distinguished from the remainder of both varieties only in leaf length $(6-8 \mathrm{~cm}$ vs $2.5-5.5 \mathrm{~cm})$. ECKENWALDER (2009) assigned the Ulleung population to var. parviflora and describes the leaves as $3-6 \mathrm{~cm}$ long and the cones as (4-) 6-8 cm long, which are different from our results. It would be premature to suggest detailed relationships of the taxa here due to the limited samples of $P$. parviflora var. pentaphylla as well as individuals from Ulleung Island.

The several taxa on Ulleung island such as Lonicera insularis Nakai (currently treated as a synonym of L. morrowii A. Gray), Tilia insularis Nakai (treated as a synonym of T. amurensis Rupr.), Acer takesimense Nakai [treated as a synonym of A. pseudosieboldianum (Pax) Kom.], and A. okamotoanum Nakai (treated as a synonym of $A$. pictum Thunb.) were described as new species before by their rather large fruits and leaves (Lonicer insularis and Acer okamotoanum), pubescent leaves (Tilia insularis), or more dissected leaves (Acer takesimense) (CHANG, 2012). Previous studies (HAVILL et al., 2008; Pfosser et al., 2002; Pfosser et al., 2005; Maekawa and Shidei, 1974; Chang, 1992; Chang et al., 2004; LIM et al., 2009) speculated that stochasticity during early Quaternary on this island had a large effect at such population margins.

In the previous allozyme study, the genetic diversity of P. parviflora on Ulleung Island was moderate (average heterozygosity $(\mathrm{He}=0.149)(\mathrm{CHUNG}$ et al., 1998), and was a little lower $(\mathrm{He}=0.259-0.272)$ than that of 16 populations examined in Japan. The extent of genetic differentiation between the Ulleung population and the Japanese populations as well as between two varieties in Japan seems to be high in terms of our current RAPD data and nuclear and mitochondrial genomes analysis (TANI et al., 2003). It seems that the majority of the island populations could be considered as one large metapopulation with geographically isolated populations as possible outliers. It seems that at the marginal population morphological variation is greatest across the geographical isolation, but the entities that comprise $P$. parviflora exhibit widely overlapping ranges in morphological attributes except leaf length.

In conclusion, based on the RAPD and DNA sequence variation from SNPs analysis including preliminary morphological analysis, it is clear that $P$. parviflora native to Ulleung Island is more related to $P$. parviflora in Japan, than P. armandii in central China. Furthermore, $P$. parviflora on Ulleung Island is closely related to var. parviflora in southern Japan based on the cones and seeds.

\section{Acknowledgement}

This study was conducted by E. H. LeE working as a visiting student under Forest Science \& Technology Projects (S210608L0101604C) provided by Korea Forest Service. We are grateful to YuJI KuRASHIGE at the Niigata Prefectural Botanical Garden, Niigata, Japan, JACK AlEXANDER at the Arnold Arboretum, Jamaica Plain, MA, USA, and HowARD HIGGINs at the Quarryhill Botanical Garden, Glen Allen, CA for providing samples for this study.

\section{References}

AHN, K. Y. (1971): Principal characteristics of Pinus parviflora $\mathrm{S}$. et Z. native to the Dagelet Island. Journal of Korean Forest Society 12: 31-43 (in Korean).

Brooks, A. J. (1999): The essence of SNPS. Gene 234: 177-186.

Businsky, R. (2004): A revision of the Asian Pinus subsection Strobus (Pinaceae). Willdenowia 34: 209-257.

Chang, C. S. (1992): A morphometric analyses of genus Acer L., section Palmata Pax, series Palmata. Korean Journal of Plant Taxonomy 21: 165-186.

ChANG, C. S. and J. I. JEON (2003): Leaf flavonoids in Cotoneaster wilsonii Nakai (Rosaceae) from the island Ulleung-do, Korea. Biochemical Systematics and Ecology 31: 171-179. 
Chang, C. S., H. Chol and K. S. Chang (2004): Reconsideration of Prunus sargentii complex in Korea: with respect to $P$. sargentii and $P$. takesimensis. Korean Journal of Plant Taxonomy 34: 221-244 (in Korean).

Chang, C. S. (2012): Illustrated Encyclopedia of Fauna \& Flora of Korea. Vol. 43. Woody Plants. Ministry of Education, Science and Technology. Designpost Press Co. (Goyang City) (in press) (in Korean).

Chung, H. G., J. M. Chung and M. G. Chung (1998): Allozyme variation in six flowering plant species characterizing Ulleung island, Korea. The Journal of Japanese Botany 73: 241-247.

DoYle, J. J. and J. L. DoYLE (1987): A rapid DNA isolation procedure for small quantities of fresh leaf tissue. Phytochemical Bulletin 19: 11-15.

ECKENWALDER, J. E. (2009): Conifers of the world: the complete reference. Timber Press (Portland, OR).

FU, L., N. Li and R. R. Mill (1999): Pinaceae, p. 11-41. In: Z. WU and P. H. RAVEN (eds.). Flora of China, Vol. 4. Science Press (Beijing, China) and Missouri Bot. Garden (St. Louis, USA).

Havill, N. P., C. S. Cambell, T. F. Vining, B. Lepage, R. J. BAyer and M. J. Donoghue (2008): Phylogeny and biogeography of Tsuga (Pinaceae) inferred from nuclear ribosomal ITS and chloroplast DNA sequence Data. Systematic Botany 33: 478-489.

Hicks, M., D. Adams, S. O'Keefe, E. McDonald and R. HodgetTs (1998): The development of RAPD and microsatellite markers in lodgepole pine (Pinus contorta var. latifolia). Genome 40: 1-9.

Hsu, C.Y., C. An, S. SAHA, D. P. MA, J. N. Jenkins, B. Scheffler and D. M. Stelly (2008): Molecular and SNP characterization of two genome specific transcription factor genes GhMyb8 an GhMyb10 in cotton species. Euphytica 159: 259-273.

Jones, C. J., K. J. Edwards, S. Castaglikone, M. O. Winfield, F. Sala, C. VAN DE Wiel, G. BREDEMEIJER, B. Vosman, M. Matthes, A. Daly, R. Brettschneider, P. Bettini, M. Buiatti, E. Maestri, A. Malcevschi, N. Marmiroli, R. Aert, G.. Volckaert, J. Rueda, R. Linacero, A. VAZqueZ and A. KARP (1997): Reproducibility testing of RAPD, AFLP, and SSR markers in plants by a network of European laboratories. Molecular Breeding 3: 381-390.

Kanetani, S., H. Ikegame, K. Tetsuka, M. Terakwwa, T. Yumonto (2004): A new population of Pinus armandii Franch. var. amamiana (Koidz.) Hatusima on Tanegashima Island, southwestern Japan. Japanese Journal of Conservation Ecology. 9: 77-82.

Kawamoto, T. (1943): Illustrated Manual of Korean Trees and Shrubs (=Chosen Shinrin Shokubutsu Zusetsu). Chosen Natural History Museum Society, Seoul (in Japanese).

LEE, T. B. (1980): Illustrated flora of Korea. Hyangmunsa, Seoul (in Korean).

LEE, D. B. and S. U. Joo (1958): Reinvestigation of the Flora of the Dagelet Island. The College of Liberal Arts and Sciences, Korea University 3: 223-296 (in Korean).

LeIBENGUTH, F. and F. SHOGHI (1998): Analysis of random amplified polymorphic DNA markers in three conifer species. Silvae Genetica 47: 120-126.

Lim, H. I., K. S. Chang, H. S. LeE, C. S. Chang and H. Kim (2009): A reappraisal of Sambucus pendula Nakai on Island Ulleung and its allies. Korean Journal of Plant Taxonomy 39: 181-192 (in Korean).

MAEKAWA, F. and T. SHIDEI (1974): Geographical Background to Japan's Flora and Vegetation. pp. 1-31. In: M.
Numata, ed. The Flora and Vegetation of Japan. Kodansha Ltd. Tokyo.

Mirov, N. T. (1967): The genus Pinus. Ronald Press. New York.

OHWI, J. (1984): Flora of Japan. p. 833-834. Smithsonian Institute, Washington, DC.

Pfosser, M. F., J. Guzy-Wrobeslka, B.-Y. Sun, T. F. Stuessy, T. SugawARA and N. FuJII (2002): The origin of species of Acer (Sapindaceae) endemic to Ulleung Island, Korea. Systematic Botany 27: 351-367.

Pfosser, M., G., P. Jakubowsky, M. SchlÜter, T. Fer, H. Kato, T. F. Stuessy and B.-Y. Sun (2005): Evolution of Dystaenia takesimana (Apiaceae), endemic to Ulleung Island, Korea. Plant Systematics and Evolution 256 159-170.

RAFALSKI, A. (2002): Applications of single nucleotide polymorphisms in crop genetics. Current Opinion in Plant Biology 5: 94-100.

RoH M. S., A. K. LeE, I. Y. ChOI, J. Y. KIM, Y. H. Joung, S. H. LEE and J. K. SUH (2007a): Characterization of the Corylopsis coreana using molecular markers. Horticulture Environment and Biotechnology 48: 176-187.

Roh, M. S., L. DE Bennedetti, Y. H. Joung and N. S. LeE (2007b): Identification of Tsuga germplasm by morphological characters and RAPD markers. Chinese Journal of Biological Control 13: 145-151.

RYun, C. J., P. QIN, J. ZHENG and Z. HE (2004): Genetic relationships among some cultivars of sea buckthorn from China, Russia and Mongolia based on RAPD analysis. Scientia Horticulturae 101: 417-426.

RYUN, C. J. (2006): Genetic relationships among sea buckthorn varieties from China, Russia, and Mongolia using AFLP markers. Journal of Horticultural Science and Biotechnology 81: 409-414.

Scheepers, D., M. C. Eloy and M. BRiquet (1997): Use of RAPD patterns for clone verification and in studying provenance relationships in Norway spruce (Picea abies). Theoretical and Applied Genetics 94: 480-485.

TANi, N., K. MaruYama, N. Tomaru, K. UChidA, M. ARAKI, Y. Tsumura, H. Yoshimaru and K. OHBA (2003): Genetic diversity of nuclear and mitochondrial genomes in Pinus parviflora Sieb. \& Zucc. (Pinaceae) populations. Heredity 91: 510-518.

WANG, H. and J. HoNG (2004): Genetic resources, tree improvement and gene conservation of five-needle pines in East Asia. USDA Forest Service Proceedings RMRSP. 32: 73-78.

Williams, J. G., A. R. Kubelik, K. J. LivaK, J. A. RAFALSKI and S. V. TINGEY (1990): DNA polymorphisms amplified by arbitrary primers are useful as genetic markers. Nucleic Acids Research 18: 6531-6535.

Wilson, E. H. (1916): The conifers and taxa of Japan. Publications of the Arnold Arboretum, no. 8. Cambridge University Press, Cambridge, UK.

Yamazaki, T. (1995): Pinaceae, p. 266-277. In: K. IwATSUKI, T. YAMAZAKI, D. E. BoufFord and H. OHBA (eds.). Flora of Japan. Vol. 1. Pteriodophyta and Gymnospermae. Kodansha, Tokyo.

YANG, S. Y. (1996): A Pioneer Study on Geology of Korean Peninsula. Kyungbuk National University Press, Taegu (Korean version).

Yoon, M. S., I. K. Choi, H. J. BaeK, J. R. LeE, C. Y. Kim, Y. H. ChO, B. S. HAHN, P. B. CREgAN and Y. H. KIM (2008): Genetic relationship of soybean cultivar by single nucleotide polymorphism (SNP) analysis. The Journal of the Korean Society of International Agriculture 20: $145-154$. 